\title{
Short Communication: Inventory of traditional medicinal plants and their uses from Atinggola, North Gorontalo District, Gorontalo Province, Indonesia
}

\author{
NOVRI YOULA KANDOWANGKO ${ }^{1, \nu}$, MUKHLISULFATIH LATIEF ${ }^{2, v v}$, RAMPI YUSUF $^{2, \text { vv }}$ \\ ${ }^{1}$ Department of Biology, Faculty of Mathematics and Natural Sciences, Universitas Negeri Gorontalo. Jl. Jenderal Sudirman No. 6, Kota Gorontalo \\ 96128, Indonesia. Tel./fax.: +62-435-821125, `email: novrikandowangko@ung.ac.id. \\ ${ }^{2}$ Department of Informatics engineering, Faculty of Engineering, Universitas Negeri Gorontalo, J1. Jenderal Sudirman No. 6, Kota Gorontalo 96128, \\ Indonesia. Tel./fax.: +62-435-821125, ^vemail: mukhlis@ung.ac.id, ^vv rampiender1@gmail.com
}

Manuscript received: 3 October 2018. Revision accepted: 14 November 2018.

\begin{abstract}
Kandowangko NY, Latief M, Yusuf R. 2018. Inventory of traditional medicinal plants and their uses from Atinggola, North Gorontalo District, Gorontalo Province, Indonesia. Biodiversitas 19: 2294-2301. Medicinal plants have been used by the people of Gorontalo as a hereditary tradition. But this knowledge has not spread to the wider community because the traditional wisdom about medicinal plants has not been documented, stored and managed properly by employing digital tools. The purpose of this study is to prepare an inventory of the traditional medicinal plants and the details of their uses in Atinggola, North Gorontalo district, Indonesia. Data has been collected by ethnobotanical survey method and analyzed using the descriptive qualitative method. The study has shown that 38 species of medicinal plants, belonging to 20 families, are used to cure many diseases by the traditional healers of Atinggola. Among them, 6 species are used to treat fever, 5 species to treat skin diseases, 2 species each to treat cancer, gastrointestinal diseases, liver diseases, and as body tonic to restore power; 1 species each to treat toothache, malaria, tonsillitis, allergies, eye irritation, wound infections and tuberculosis (TBC). Plant parts used in the treatment practices are leaf, fruit, flower, rhizome, root, stem, seed, shoots, midribs parts, etc. However, the most dominant part used is the leaf of the plants. Various methods such as boiling, squeezing, scraping, chewing, smashing, brewing, etc. are used to prepare the medicines. 29 species $(76.31 \%)$ of medicinal plants are collected from cultivated sources such as backyards and gardens while 9 species $(23.68 \%)$ are still sourced from forests.
\end{abstract}

Keywords: Ethno medicinal diversity, Gorontalo, medicinal plant, traditional medicines

\section{INTRODUCTION}

Atinggola is one of the sub-distrct located in the district of North Gorontalo, Gorontalo Province, Indonesia. It is inhabited by several civil society groups who have come from Ternate, Sangir and Gorontalo. Atinggola communities still maintain their tradition regarding the use of medicinal plants. This is evidenced by the fact that there are still many traditional medicinal experts (healers or shamans) who utilize plants as the main raw materials in the treatments provided. Their knowledge of the use of plants as medicine is based on the experiences they have gained in trying to meet the treatment needs using a variety of local plants. The number of patients visiting these traditional healers of Atinggola is between 10-30 people/month per healer.

Also, many species of medicinal plants are found in the Atinggola region and the people use the various parts of these plants or whole plants to maintain the health of their family members. Their livelihood as farmers is also in line with their interest in using traditional medicinal plants for curing diseases and maintenance of family health and also the preservation of medicinal plants by cultivating them in backyards and gardens. Currently, there is a shift in their opinion regarding use of traditional medicines. They now know about modern medicines and some of them have already abandoned using traditional medicines and prefer to use modern medicines which provides quick results. However, some of them, especially the native residents and farmers, still continue using traditional medicines and preserve this traditional healing heritage. It is necessary to strengthen and preserve the local wisdom of Atinggola community pertaining to medicinal plants.. Therefore, this ethnobotanical study of medicinal plants used by traditional healers in Atinggola Sub-district, Gorontalo, Indonesia, was conducted in order to know the local knowledge of medicinal plants, parts of the plants used as medicines and the processing of medicinal plants.

This is also to strengthen the research that has been done for other Atinggola regions, which was carried out in 2012, namely the exploration of local knowledge of ethnomedicine and community-based medicinal plants in Indonesia which reported that there were 64 plants and 48 herbs used on Atinggola. ethnic group (Kandowangko et al. 2012)

\section{MATERIALS AND METHODS}

The study was conducted in four villages, namely Pinontoyonga, Ilohelumo, Tombulilato and Sigaso of Atinggola, North Gorontalo district, Province Gorontalo, 
Indonesia (Figure 1), using the survey method. Data and information collected about traditional medicinal uses of plants was done by interviews and direct observations in the field. Interviews were conducted with the traditional healers (shamans) and locals who know about or use the plants around them to treat diseases (Rahayu et al. 2002). For each plant species used as medicine, the following information was collected and recorded: local name, place of growth, parts used, method of use, and uses. The tools used in this study were: recorder, digital camera, notebooks, pens, scissors, plastic bags and questionnaires. A combination of qualitative and quantitative methods were used to collect ethnobotanical information, through in-depth interviews with respondents using open ended questionnaires. Respondents were selected using purposive sampling, based on certain criteria. Along with collection of information on medicinal plants from the community, the medicinally useful plants were collected from backyards, home gardens and forests located around the hamlet. Every plant was identified using local name and scientific name. Unidentified plants were photographed and also herbarium materials collected for further identification by botanist in the Laboratory of Botany, Department of Biology, Faculty of Mathematic and Natural Science, Gorontalo State University, Indonesia. The plants were identified using Steenis (2006). The information thus collected were analyzed descriptively and quantitatively using tables.

\section{RESULTS AND DISCUSSION}

Results of this study indicate that 38 species of medicinal plants, belonging to 27 Genera and 20 families, are used by traditional healers in the Atinggola community (Table 1). The most widely used medicinal plants are from Euphorbiaceae, Oxalidaceae and Zingerberaceae. From each of these families, four species were found to be used as medicinal which accounts for $10.53 \%$ of the total number of species recorded as medicinal in this study (Table 2). 20 species of Medicinal plants used are trees, 8 are herbs, 3 are shrubs, 4 grasses and 5 are lianas (Figure 2).

From interviews with traditional healers of Atinggola, it was known that medicinal herbs are used not only for the treatment of relatively common and mild diseases such as ulcers, itchy skin, eye irritations, wounds and infections, but also in the treatment of severe diseases such as dengue fever, malaria, kidney stones and even cancer (table 3). Treatment for such diseases was generally demanded by the local community because of the lack of health care facilities in the accessible surroundings. There is only one simple health center located in the study area.

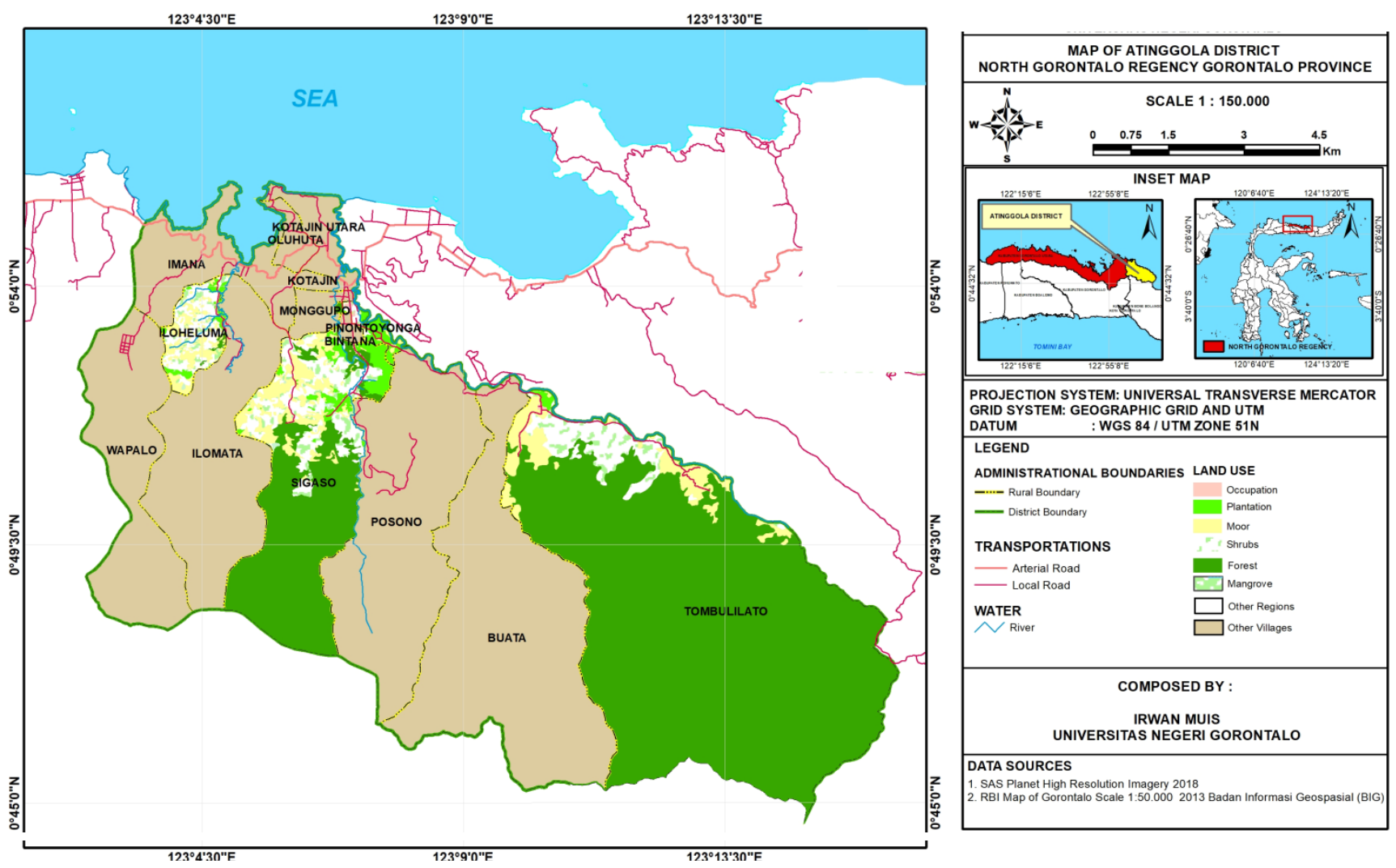

Figure 1. Location of study villages of Atinggola, District North Gorontalo, Province Gorontalo, Indonesia 
Table 1. Medicinal plants used by traditional healers of Atinggola Community: Information is listed in this order-Family name, scientific name, life form, vernacular name, parts used, additional materials added, processing/method of application and health benefits/diseases treated

\begin{tabular}{|c|c|c|c|c|c|c|}
\hline Family/ scientific name & $\begin{array}{l}\text { Growth } \\
\text { form }\end{array}$ & Vernacular name & $\begin{array}{l}\text { Parts of } \\
\text { plant }\end{array}$ & Additional material & Processing/Method of application & $\begin{array}{l}\text { Health benefits } \\
\text { or diseases } \\
\text { claimed to be } \\
\text { treated }\end{array}$ \\
\hline \multirow[t]{2}{*}{$\begin{array}{l}\text { Euphorbiaceae } \\
\text { Jatropha curcas L. }\end{array}$} & Tree & $\begin{array}{l}\text { Balacae, binthalo } \\
\text { (Gorontalo) }\end{array}$ & Leaf & Coconut oil & $\begin{array}{l}\text { Leaves smeared with coconut oil, heated over the fire, paste of the } \\
\text { heated leaves applied on the forehead }\end{array}$ & Fever \\
\hline & & & Leaf & $\begin{array}{l}\text { Dried banana leaves, black } \\
\text { coffee }\end{array}$ & $\begin{array}{l}\text { Mixed with dried leaves of Musa x paradiasiaca } \mathrm{L} \text {. and boiled and the } \\
\text { water decoction used for bathing and also applied on the body of of } \\
\text { puerperal mothers. After bathing, drinking black coffee is advised to } \\
\text { stop bleeding and increase their strength. }\end{array}$ & $\begin{array}{l}\text { Energy recovery } \\
\text { after child } \\
\text { delivery }\end{array}$ \\
\hline \multirow[t]{2}{*}{$\begin{array}{l}\text { Macaranga tanarius (L.) } \\
\text { Müll.Arg. }\end{array}$} & Tree & $\begin{array}{l}\text { Kayu mata putih } \\
\text { (Gorontalo, Indonesia) }\end{array}$ & Leaf & & Leaves kneaded and massaged on the itchy skin & Skin Itches \\
\hline & & & Leaf & $\begin{array}{l}\text { Hedyotis corymbosa (L.) } \\
\text { Lam., Jatropha curcas L., } \\
\text { Hibiscus tiliaceus var. } \\
\text { abutiloides (Willd.) Hochr. }\end{array}$ & 3 pieces of each leaf mixed, boiled and the boiled water consumed. & Fever \\
\hline Acalypha indica $\mathrm{L}$. & Herb & $\begin{array}{l}\text { Luata (Gorontalo), } \\
\text { Kucing-kucingan } \\
\text { (Indonesia) }\end{array}$ & Leaf & & The leaves are crushed and placed in aching teeth cavities & Toothache \\
\hline $\begin{array}{l}\text { Melanolepis } \\
\text { multiglandulosa } \\
\text { (Reinw.ex Blume) } \\
\text { Rchb.f.\& Zoll. } \\
\text { Arecaceae }\end{array}$ & Shrub & $\begin{array}{l}\text { Walongo (Gorontalo); } \\
\text { Kayu kapur (Indonesia) }\end{array}$ & Leaf & $\begin{array}{l}\text { rhizomes of Kaempferia } \\
\text { galanga L., Garlic cloves }\end{array}$ & $\begin{array}{l}\text { Leaves mixed with } 1 \text { clove of garlic and rhizomes Kaempferia galanga } \\
\text { L., and the water extract is dripped into the nose. }\end{array}$ & Nose breeding \\
\hline Cocos nucifera $\mathrm{L}$. & Tree & $\begin{array}{l}\text { Kelapa (Gorontalo, } \\
\text { Indonesia) }\end{array}$ & $\begin{array}{l}\text { tender } \\
\text { coconut } \\
\text { meat }\end{array}$ & $\begin{array}{l}\text { Leaves of Curcuma longa } \\
\text { L. (leaves (Turmeric), } \\
\text { leaves of Pandanus } \\
\text { amaryllifolius Roxb. } \\
\text { leaves, fruits of Citrus } \\
\text { limon (L.) Osbeck }\end{array}$ & $\begin{array}{l}\text { Tender coconut meat shredded and mixed with lemon leaves, turmeric } \\
\text { leaf and pandan leaves. The herbal mixture is consumed three times a } \\
\text { day }\end{array}$ & $\begin{array}{l}\text { Increases breast } \\
\text { milk }\end{array}$ \\
\hline \multirow[t]{2}{*}{$\begin{array}{l}\text { Oxalidaceae } \\
\text { Averrhoa carambola } \mathrm{L} .\end{array}$} & Tree & $\begin{array}{l}\text { Balimbi (Gorontalo); } \\
\text { Belimbing manis } \\
\text { (Indonesia) }\end{array}$ & Leaf & - & Juice of the leaves taken orally, paste is applied on the itchy skin & Skin itches \\
\hline & & & Leaf & $\begin{array}{l}\text { Leaves of Averrhoa } \\
\text { bilimbi, dumbaya } \\
\text { (Dombeya acuminatissima } \\
\text { Hochr.), turmeric, bungale, } \\
\text { onion, garlic, }\end{array}$ & $\begin{array}{l}\text { Mixed with leaves of Averrhoa bilimbi L. and one part each of } \\
\text { dumbaya, turmeric, bungale, red onion and a clove of garlic. All the } \\
\text { ingredients are mixed well in } 150 \mathrm{ml} \text { of water. }\end{array}$ & Measles \\
\hline
\end{tabular}




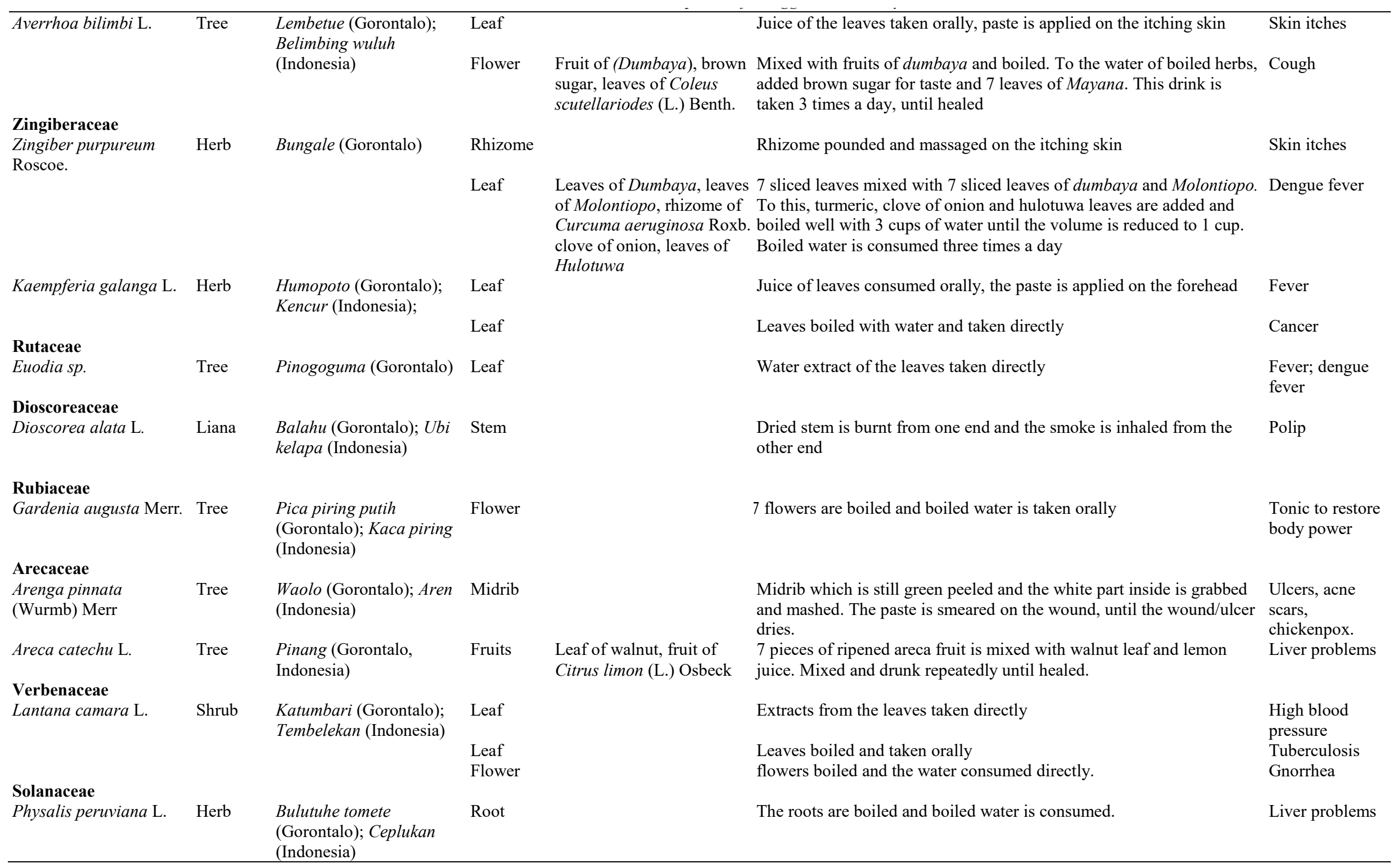




\begin{tabular}{|c|c|c|c|c|c|c|}
\hline $\begin{array}{l}\text { Gnetaceae } \\
\text { Gnetum gnemon L. }\end{array}$ & Tree & $\begin{array}{l}\text { Ganemo (Gorontalo) } \\
\text { Melinjo (Indonesia) }\end{array}$ & Leaf & & Leaves cooked and eaten like vegetables & Indigestion \\
\hline $\begin{array}{l}\text { Cyperaceae } \\
\text { Miscanthus sinensis } \\
\text { Andersson }\end{array}$ & Grass & $\begin{array}{l}\text { Diata (Gorontalo); } \\
\text { Rumput Pisau (Indonesia) }\end{array}$ & Leaf & & The leaves are crushed and smeared on the head & Headache \\
\hline & & & $\begin{array}{l}\text { Flower } \\
\text { and seed }\end{array}$ & & Dried flowers and seeds mashed, brewed with hot water and drunk. & Cancer \\
\hline & & & Fruits & & $\begin{array}{l}7 \text { pieces of the fruits chewed and the resulting paste is smeared on the } \\
\text { tumor or abscess without eye, until it changes color from reddish to } \\
\text { pale or ruptures. }\end{array}$ & $\begin{array}{l}\text { Tumors or } \\
\text { ulcers which are } \\
\text { eyeless or not } \\
\text { ruptured. }\end{array}$ \\
\hline $\begin{array}{l}\text { Menispermaceae } \\
\text { Arcangelisia flava } \\
\text { (L.)Merr }\end{array}$ & Liana & $\begin{array}{l}\text { Ayulalahe (Gorontalo); } \\
\text { Kayu kuning (Indonesia) }\end{array}$ & Root & & the roots are boiled and the boiled water is drunk & $\begin{array}{l}\text { Body fitness, } \\
\text { tonic }\end{array}$ \\
\hline & & & Stem & Rhizomes of ginger & $\begin{array}{l}\text { The stem and ginger rhizome made into a decoction in boiling water } \\
\text { which is drunk }\end{array}$ & Breathlessness \\
\hline Caricaceae & & & & & & \\
\hline Carica papaya $\mathrm{L}$. & Tree & Pepaya & Leaf & & Yellow leaves boiled and boiled water is given to drink & Malaria \\
\hline Malvaceae & & & & & & \\
\hline Theobroma cacao L. & Tree & Coklat & $\begin{array}{l}\text { Leaf } \\
\text { Friut }\end{array}$ & & $\begin{array}{l}\text { Brown leaves boiled and boiled water is given to drink } \\
\text { Chocolate made from fruit is scraped and smeared on the wound } \\
\text { surface }\end{array}$ & $\begin{array}{l}\text { Diabetes melitus } \\
\text { Wounds }\end{array}$ \\
\hline $\begin{array}{l}\text { Cucurbitaceae } \\
\text { Cucurbita maxima } \\
\text { Duchesne }\end{array}$ & Herb & $\begin{array}{l}\text { Sambiki (Gorontalo) } \\
\text { Labu kuning }\end{array}$ & Sap & & The sap from the stem is smeared on the forehead and scalp. & Headache \\
\hline $\begin{array}{l}\text { Musaceae } \\
\text { Musa x paradiasiaca } \mathrm{L} \text {. }\end{array}$ & Tree & Pisang raja & Fruit & & Fruits consumed before meals & Ulcer \\
\hline $\begin{array}{l}\text { Poaceae } \\
\text { Bambusa affinis Munro }\end{array}$ & Tree & Buluh (Gorontalo) & Shoots & & $\begin{array}{l}\text { Shredded and added salt to taste, and boiled with } 3 \text { cups of water until } \\
\text { the volume reduces to } 1 \text { cup. Consumed orally }\end{array}$ & Diabetes melitus \\
\hline $\begin{array}{l}\text { Polygonaceae } \\
\text { Polygonum barbatum } \mathrm{L} \text {. }\end{array}$ & Herb & $\begin{array}{l}\text { Tolowe (bahasa } \\
\text { Atinggola); Poombito } \\
\text { (Gorontalo) }\end{array}$ & Shoots & & Boiled and the boiled water orally taken. & Fever \\
\hline $\begin{array}{l}\text { Moraceae } \\
\text { Ficus septica Burm L. }\end{array}$ & Tree & $\begin{array}{l}\text { Bualo (Gorontalo), Awar- } \\
\text { awar (Indonesia) }\end{array}$ & Shoots & & Shoots boiled and the boiled water drunk. & $\begin{array}{l}\text { Poisones, } \\
\text { allergies }\end{array}$ \\
\hline
\end{tabular}


Table 2. Proportion of genera and species belonging to various families used as medical plants in Atinggola, Gorontalo, Indonesia

\begin{tabular}{lcccc}
\hline \multicolumn{1}{c}{ Family } & $\begin{array}{c}\text { Number } \\
\text { of } \\
\text { genera }\end{array}$ & $\begin{array}{c}\text { Proportion } \\
\text { of total } \\
\text { genera } \\
\mathbf{( \% )}\end{array}$ & $\begin{array}{c}\text { Number } \\
\text { of } \\
\text { species }\end{array}$ & $\begin{array}{c}\text { Proportion } \\
\text { of total } \\
\text { species } \\
\mathbf{( \% )}\end{array}$ \\
\hline Euphorbiaceae & 2 & 7.41 & 2 & 5.26 \\
Arecaceae & 3 & 11.11 & 3 & 7.89 \\
Euphorbiaceae & 3 & 11.11 & 4 & 10.53 \\
Oxalidaceae & 2 & 7.41 & 4 & 10.53 \\
Zingiberaceae & 2 & 7.41 & 4 & 10.53 \\
Rutaceae & 1 & 3.70 & 1 & 2.63 \\
Dioscoreaceae & 1 & 3.70 & 1 & 2.63 \\
Rubiaceae & 1 & 3.70 & 1 & 2.63 \\
Verbenaceae & 1 & 3.70 & 3 & 7.89 \\
Solanaceae & 1 & 3.70 & 1 & 2.63 \\
Gnetaceae & 1 & 3.70 & 1 & 2.63 \\
Cyperaceae & 1 & 3.70 & 3 & 7.89 \\
Menispermaceae & 1 & 3.70 & 2 & 5.26 \\
Caricaceae & 1 & 3.70 & 1 & 2.63 \\
Malvaceae & 1 & 3.70 & 2 & 5.26 \\
Cucurbitaceae & 1 & 3.70 & 1 & 2.63 \\
Musaceae & 1 & 3.70 & 1 & 2.63 \\
Poaceae & 1 & 3.70 & 1 & 2.63 \\
Polygonaceae & 1 & 3.70 & 1 & 2.63 \\
Moraceae & 1 & 3.70 & 1 & 2.63 \\
Total & 27 & 100 & 38 & 100 \\
\hline
\end{tabular}

Out of the total 38 species of medicinal plants used by herbalists or traditional healers in Atinggola, number of species used in the treatment of different diseases are: 6 species to treat fever, 5 species to treat skin diseases
Table 3. Types of diseases cured with medicinal plants

\begin{tabular}{ll}
\hline $\begin{array}{l}\text { Types of } \\
\text { diseases }\end{array}$ & Name of diseases / health benefits \\
\hline Mild diseases & $\begin{array}{l}\text { Fever, Energy recovery post-partum, To } \\
\text { increase breast milk, Itching skin, Toothache, } \\
\text { Measles, Cough, Polyp's, Tonic to restore } \\
\text { power, Ulcers, Acne scars, Chickenpox, } \\
\text { Poisoning, Allergy, Nose bleeding, Wounds, } \\
\text { Headache and Indigestion }\end{array}$ \\
& $\begin{array}{l}\text { Cancer, High blood pressure, Tuberculosis } \\
\text { (TBC), Gonorrhoea, Liver disorders, } \\
\text { Diabetes mellitus, Malaria and Dengue fever }\end{array}$ \\
\hline
\end{tabular}

(ulcers), 2 species each to treat cancer, gastrointestinal diseases, liver diseases, and as body tonic to restore power; 1 species each to treat toothache, malaria, tonsillitis, allergies, eye irritation, wound infections, and tuberculosis (TBC). The six species used to treat fever are: Jatropha curcas, Macaranga tanarius, Zingiber purpureum, Kaempferia galanga, Euodia redlevi, and Polygonum barbatum.

In addition, there are traditional beliefs associated with the collection of plant parts for medicinal purposes. For example, while collecting plant parts from the forest plants, one cannot wear red colored shirt. Also, the herbaceous plant species should be harvested before sunrise or 06.00 pm. Water used in the processing of ingredients must be the water that has been used for cooking. The bark of the tree must be collected in the dry season, when the trunk was chipped.

Table 4. Reported medicinal uses for ethno medicinal plants of Atinggola in published literature

\begin{tabular}{|c|c|c|c|c|}
\hline Family & Plant & Diseases/uses & $\begin{array}{l}\text { Plant parts } \\
\text { used }\end{array}$ & Reference \\
\hline \multirow[t]{3}{*}{ Arecaceae } & Cocos nucifera L. & Measles & $\begin{array}{l}\text { Milk from tender } \\
\text { coconut }\end{array}$ & Lense (2012) \\
\hline & & Nerve system & Root & Nahdi et al. 2016 \\
\hline & & itchy skin & Endosperm & Nahdi et al. 2016 \\
\hline Euphorbiaceae & $\begin{array}{l}\text { Macaranga tanarius } \\
\text { Muelll. Arg }\end{array}$ & Chest pain, malaria & Leaves & Lense (2012) \\
\hline Zingiberaceae & Zingiber purpureum Roxb & Body's immune system & Rhizome & Nahdi et al (2016) \\
\hline Zingiberaceae & Kaempferia galanga $\mathrm{L}$ & $\begin{array}{l}\text { Cough, ashma, gastrointestinal disorders, } \\
\text { stomach ache, rheumatism, aphrodisiac, } \\
\text { fever }\end{array}$ & Rhizome & Silalahi et al. (2015) \\
\hline Arecaceae & Areca catechu L. & Bone Fractures, Busung, Tinuktuk tawar & Fruit & Silalahi et al. (2015) \\
\hline Caricaceae & Carica papaya $\mathrm{L}$ & Malaria & Leaves & Lense (2012) \\
\hline Musaceae & Musa paradiasiaca, L. & Easy birth & Stem & Lense (2012) \\
\hline Poaceae & Bambusa sp. & Wounds & Outer bark & Lense (2012) \\
\hline \multirow[t]{3}{*}{ Polygonaceae } & Polygonum barbatum L. & Scabies & Roots & Lense (2012) \\
\hline & & Abcesses & Leaves & Lense (2012) \\
\hline & & Dysentery & Leaves & Lense (2012) \\
\hline \multirow[t]{2}{*}{ Moraceae } & Ficus septica Burm. L. & Abscesses & Bark, shoot & Lense (2012) \\
\hline & & Eye infection & Leaves & Lense (2012) \\
\hline
\end{tabular}



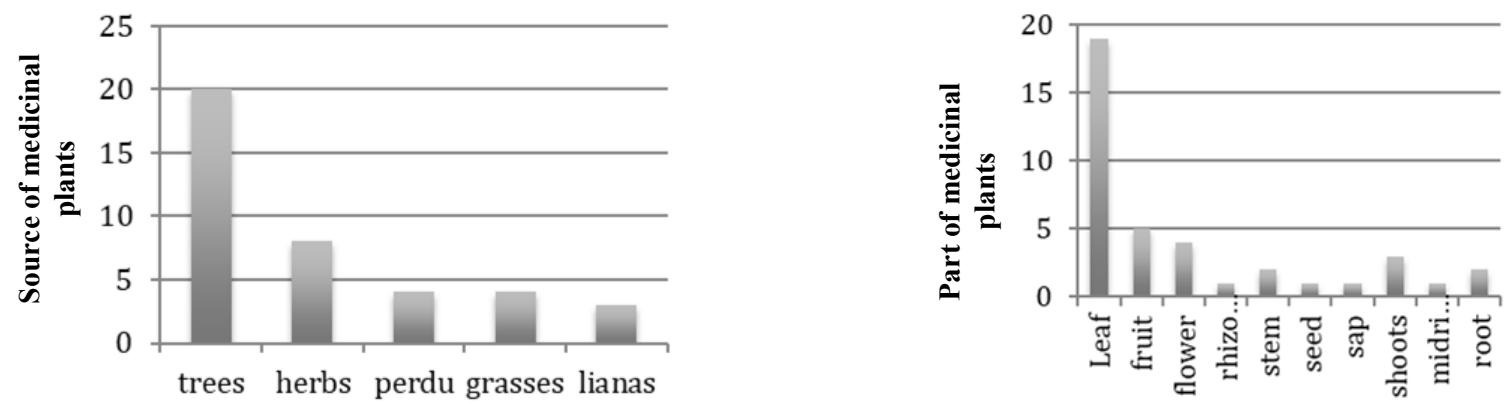

Figure 2. Proportion of medicinal plants of Atinggola based on: growth form (left), and part of the plants used (right)

A review of published literature has indicated that the medicinal plants used by the people of Atinggola have been also used by communities in other areas, either to treat the same or different diseases/purposes (table 4). For example, people of Atinggola use tender coconut (Cocos nucifera) meat to increase breast milk production, while it is used for treating measles in Manokwari, West Papua (Lense 2012), and Turgo community of Yogyakarta use roots of this plant to treat problems of nerve system and endosperm to treat itchy skin (Nahdi et al 2016). In both Atinggola and Manokwari of West Papua, Carica papaya is employed as a cure for malaria (Lense, 2012). The rhizome of Zingiber purpureum is used as a remedy for Itchy skin and its leaves are used for the treatment of dengue fever, in the present study. This is almost similar to the report of Nahdi et al. (2016).

Another significant finding is that people of Atinggola have a practice of planting medicinal plants in their backyards or home gardens. Data obtained during the present study regarding the source of medicinal plants indicated that $76.31 \%$ or 29 species are obtained from cultivated sources, among which $44.74 \%$ medicinal plants are collected from home gardens and $31.58 \%$ are from backyards. Only 9 species or $23.68 \%$ medicinal plants are obtained from natural forests. This proves that the people in Atinggola are aware of the necessity and importance of preserving biodiversity. Therefore, they have tried to cultivate medicinal plants that they use in their traditional medicinal systems. This stresses again on the need to document and preserve public knowledge on the use of medicinal plants as a traditional healing heritage to maintain family health and also to protect local biodiversity. Further, the community knowledge needs to be scientifically authenticated and improved through research on isolating active substances from medicinal plants, which should be carried out by scientific and academic institutions like universities. So, continuous research is needed to develop traditional knowledge both qualitatively and quantitatively which is also important to protect the local wisdom of the community as the collective intellectual property of the Indonesian people.

\section{ACKNOWLEDGEMENTS}

The authors wish to thank the Directorate General of Research and Development, Indonesian Ministry of Research, Technology and Higher Education for funding this research through DIPA Number SP DIPA042.06.1.401516/2018, dated 5 December 2017 and according to the Higher Applied University research contract for 2018 fiscal year with contract number: 249 / UN47.D / PL / 2018. Authors gratitudes and appreciations are also due to all the traditional healers of the Atinggola community who have provided information about the medicinal plants.

\section{REFERENCES}

Dalimartha S. 2000. Indonesian Plant Atlas. Trubus Agriwidya, Jakarta Gechev TS, Hille J, Woerdenbag HJ, Benina M, Mehterov N, Toneva V, Fernie AR, Roeber BM. 2014. Natural products from resurrection plants: Potential for medical applications. Research review paper. Biotechnol Adv 32: 1091-1101.

Kandowangko NY, Junus R, Hasan H, Lamangantjo CJ, Adam R. 2012. Research Report Specifically Exploring Ethnomedical Knowledge and Community-Based Medicinal Plants in Indonesia (Atinggola Ethnicity). Collaborative Research from Gorontalo State University and Health Research and Development Agency, Jakarta.

Kinho J, Arini DID, Halawane J, Nurani L, Halidah, Kafiar Y, Karundeng MC. 2011. Plants of Traditional Medicines in North Sulawesi, Volume II. Balai Penelitan Kehutanan, Manado.

Lense O. 2012. The wild plants used as traditional medicines by indigenous people of Manokwari, West Papua. Biodiversitas 13 (2): 98-106.

Mahmood A, Mahmood A, Malik RN, Shinwari ZK. 2013. Indigenous knowledge of medicinal plants from Gujranwala district, Pakistan. J Ethnopharmacol148 (2): 714-723.

Nahdi MS, Nugraheni IKA, Martiwi ARI, Arsyah DC. 2016. The ethnobotany of medicinal plants in supporting the family health in Turgo, Yogyakarta, Indonesia. Biodiversitas 17 (2): 900-906.

Rai MK, Carpinella C. 2006. Naturally Occurring Bioactive Compounds. Elsevier, Amsterdam.

Silalahi M, Supriatna J, Walujo EB, Nisyawati. 2015. Local knowledge of medicinal plants in sub-ethnic Batak Simalungun of North Sumatra, Indonesia. Biodiversitas 16 (1): 44-54.

Setyowati FM. 2010. Ethnopharmacology and the use of plants among Dayak Tunjung Tribe in East Kalimantan. Media Litbang Kesehatan 3: 104-112.

Steenis CGGJ van. 2006. Mountain Flora of Java. 2nd ed. E.J. Brill, Leiden. 
Simbala HE.I 2007. Floristic and the Use of Medicinal Plant by Community in Bogani Nani Wartabone National Park. [Dissertation]. Institut Pertanian Bogor, Bogor. [Indonesian]

Tjitrosoepomo G. 2010. Plant Morphology. GMU Press, Yogyakarta, Indonesia. [Indonesian]

Rahayu M, Rugayah, Praptiwi, Hamzah. 2002. Diversity in the use of medicinal plants by the Sasak tribe in Gunung Rinjani National Park, Lombok, NTB. In: Naiola BP, Chairul DSH, Hoesen, Hartutiningsih, Utami NW, Panggabean G, Praptiwi, Purwanto, Kahono S, Juhaeti T, Jamal Y, Suryasari Y. 2001. Proceedings of Symposium II. Medicinal and Aromatic Plants, Biology Research Center-LIPI, KEHATI,
APINMAP, UNESCO, and JICA, Bogor, August 8-10, 2001. [Indonesian]

Varalakshmi CH, Ali AM, Pardhasaradhi BVV. 2008. Immunomodulatory effect of curcumin: in vivo. Intl J Immunol 8: 688-700.

Windadri FI, Rahayu M, Uji T, Rustiani H. 2006. The use of plants as medicinal ingredients by the local community of the Muna tribe in Wakarumba Sub-district, Muna District, Sulawesi. Biodiversitas 7 (4): 333-339. [Indonesian]

Zuhud EAM. 2009. The potential of tropical forest as the buffer for natural medicine material for the nation's health. Jurnal Bahan Alam Indonesia 6 (6): 227-232. 